\title{
SUPPLY AND SUBSTITUTION OPTIONS FOR SELECTED CRITICAL RAW MATERIALS: COBALT, NIOBIUM, TUNGSTEN, YTTRIUM AND RARE EARTHS ELEMENTS
}

\author{
Andreas Bartl *,1, Alan H. Tkaczyk ${ }^{2}$, Alessia Amato ${ }^{3}$, Francesca Beolchini ${ }^{3}$, Vjaceslavs \\ Lapkovskis ${ }^{4}$ and Martina Petranikova ${ }^{5}$ \\ ${ }^{1}$ Vienna University of Technology, Institute of Chemical, Environmental \& Bioscience Engineering, Getreidemarkt 9/166, \\ 1060 Vienna, Austria \\ 2 University of Tartu, Institute of Physics, W. Ostwaldi Street 1, 50411 Tartu, Estonia \\ ${ }^{3}$ Polytechnic University of Marche, Department of Life and Environmental Sciences-DiSVA, via Brecce Bianche, 60131, Ancona, Italy \\ ${ }^{4}$ Riga Technical University, Lomonosova str 1A/1, 1019 Riga, Latvia \\ ${ }^{5}$ Chalmers University of Technology, Department of Chemistry and Chemical Engineering, Kemivägen 4, 42196 Gothenburg, Sweden
}

Article Info:

Received:

25 January 2018

Revised:

11 July 2018

Accepted:

22 August 2018

Available online:

10 September 2018

Keywords:

Circular economy

Recycling

Critical raw materials

\section{ABSTRACT}

European industry is dependent on the import of raw materials. The European Commission has recognized that some raw materials are crucial for the function of the European economy and show a high risk of supply shortage. This communication addresses supply and substitution options for selected critical raw materials: cobalt, niobium, tungsten, yttrium, and the rare earth elements. For each element, the most relevant data concerning mining, abundance, recycling rates and possible substitutes are summarized and discussed.

\section{INTRODUCTION}

The availability of certain raw materials is crucial to Europe's economy (EC 2014). The COST Action CA15102, Solutions for Critical Raw Materials (CRM) Under Extreme Conditions (www.crm-extreme.eu), focuses on the substitution of CRMs in high value alloys and metal-matrix composites used under extreme conditions of temperature, loading, friction, wear, corrosion, in energy, transportation and machinery manufacturing industries. Presently, the European Commission identifies 26 raw materials or groups of raw materials of strategic importance; these materials exhibit both a high supply risk and important economic impact (EU 2017). The present communication reviews the current situation for a subset of this list: cobalt, niobium, tungsten, yttrium, and the rare earth elements (REE). It is evident that a strategy should be developed for the identified materials to close the loop and minimize the demand for virgin resources.

\section{STATE-OF-THE-ART}

\subsection{Cobalt}

Cobalt (Co) belongs to group 9 of the periodic table.
The interest in Co is due to its industrially useful properties including ductility, malleability and magnetizability. These characteristics, combined with heat resistance (melting point $1495^{\circ} \mathrm{C}$ and boiling point $2870^{\circ} \mathrm{C}$ ) and strength, make cobalt suitable for a wide variety of industrial and military applications (Minerals UK 2009).

Co has been known since ancient times. The first evidence dates to 2600 B.C., when blue glazed pottery was found in Egyptian tombs. Co-containing materials have been used as pigments for decades. The pure metal was isolated by Georg Brandt in 1735 (Donaldson and Beyersmann 2005).

The vast majority of Co is mined in Congo, which accounted for $54 \%$ of mine production in 2016 . Furthermore, about half of the global reserves of Co are estimated to be in Congo. The importance of other countries is limited, with the individual share of other countries not exceeding $6 \%$. Table 1 gives an overview of the geographical distribution of Co mining and reserves.

Typically, Co is used for metallurgical applications, as a component of superalloys, for the building of turbine engines for aircrafts, in the chemical sector (catalysts, adhesives, pigments, agriculture, and medicine), for the 
TABLE 1: World Mine Production and estimated reserves of Co (Shedd 2017a).

\begin{tabular}{|c|c|c|c|c|}
\hline & \multicolumn{2}{|c|}{ Mine production 2016} & \multicolumn{2}{|c|}{ Estimated reserves } \\
\hline & [t] & Share & {$[1000 \mathrm{t}]$} & Share \\
\hline Congo & 66,000 & $54 \%$ & 3,400 & $49 \%$ \\
\hline China & 7,700 & $6 \%$ & 80 & $1 \%$ \\
\hline Canada & 7,300 & $6 \%$ & 270 & $4 \%$ \\
\hline Russia & 6,200 & $5 \%$ & 250 & $4 \%$ \\
\hline Australia & 5,100 & $4 \%$ & 1,000 & $14 \%$ \\
\hline Zambia & 4,600 & $4 \%$ & 270 & $4 \%$ \\
\hline Cuba & 4,200 & $3 \%$ & 500 & $7 \%$ \\
\hline Philippines & 3,500 & $3 \%$ & 290 & $4 \%$ \\
\hline Madagascar & 3,300 & $3 \%$ & 130 & $2 \%$ \\
\hline New Caledonia & 3,300 & $3 \%$ & 64 & $1 \%$ \\
\hline South Africa & 3,000 & $2 \%$ & 29 & $0 \%$ \\
\hline United States & 690 & $1 \%$ & 21 & $0 \%$ \\
\hline Other countries & 8,300 & $7 \%$ & 690 & $10 \%$ \\
\hline World total (rounded) & 123,000 & & 7,000 & \\
\hline
\end{tabular}

production of cemented carbides, and for the ceramics and enamels industry (CDI 2006). Nevertheless, the most common application is the manufacture of lithium-ion batteries, used for the power supply of electronic equipment. China is the leading consumer of cobalt, with nearly $80 \%$ of its consumption being used by the rechargeable battery industry (Shedd 2017a).

The recycling of $\mathrm{Co}$ is massively dependent on the application. Co-containing alloys are reprocessed into similar alloys and do not require a specific recycling technology. Hardmetal scrap is commonly recovered within the metal carbide sector. As lithium-ion batteries are the most common application, several recycling procedures have been developed for this area. The process commonly starts with reductive leaching (e.g. $\mathrm{H}_{2} \mathrm{SO}_{4}, \mathrm{H}_{2} \mathrm{O}_{2}$ ) followed by extraction and cobalt precipitation (Chen et al 2011, Pagnanelli et al 2016, Jian et al 2012). Cobalt recycling from applications in pigments, glass, paints, etc. is not readily possible as these usages are dissipative (EU 2016).

Table 2 summarizes possible substitutes for Co. For some applications, however, Co is essential as substitution would lead to a loss of product performance. This is in particular the case for the application with the highest share, lithium-ion batteries (25\%). Even though intensive research is being conducted in this area, a short-term breakthrough cannot be expected (Nayak 2017).

Considering the many uses, the recent Co demand has grown and it is essential to counteract the increased production of waste with increased recovery efforts (Cheang and Mohamed, 2016). According to EC 1014b, the end-oflife recycling input rate in the European Union in 2014 was $16 \%$. For the USA, a recycling rate of $32 \%$ was reported in 1998 (Shedd 2004). In a more recent document, however, the EU Commission estimates the end-of-life recycling input rate to be zero (EC 2017).

\subsection{Niobium}

Niobium is a transition element of group 5. Due to its properties, it belongs to the group of refractory metals
(Bauccio 1993). A Nb-containing oxide was first described by Charles Hatchett in 1801 who proposed the name Columbium (Hatchett 1802). Due to its similar properties, $\mathrm{Nb}$ could not be distinguished from Tantalum until 1865. Even if the official IUPAC name is Niobium (Nb), the name Columbium (Cb) is still widely used in North America.

$\mathrm{Nb}$ reserves are virtually inexhaustible (Schulz and Papp 2014), but are classified as critical due to the high production and deposit concentration in Brazil, as shown in Table 3.

Ferroniobium is by far the most important application for $\mathrm{Nb}$ and consumes almost $90 \%$ of the market (TIC 2016). Ferroniobium itself is used almost exclusively as an alloying element for steels containing $\mathrm{Nb}$. In particular steel numbers starting with 1.45 or 1.46 may contain $\mathrm{Nb}$, even if the concentration is below $1 \%$ (DIN 2014). Other end-uses are $\mathrm{Nb}$ chemicals, vacuum-grade $\mathrm{Nb}$ master alloys, pure $\mathrm{Nb}$ metal and $\mathrm{Nb}$ alloys such as $\mathrm{NbTi}$ (TIC 2016).

Commonly, $\mathrm{Nb}$ is not recycled as pure element but $\mathrm{Nb}$-containing steels and superalloys are recycled for the same alloy. Thus, Nb recycling is not a question of technology, but of logistics. According to Papp (2017), the amount of recycled $\mathrm{Nb}$ is not available, but it may be as high as $20 \%$. However, other sources report recycling rate of $56 \%$ (Birat and Sibley 2011). As Nb is used in relatively low concentrations (<1\%) in alloys (DIN 2014), separate handling of $\mathrm{Nb}$ is often not worthwhile. Therefore, the element is strongly diluted in iron scrap, where it no longer has any function. Only recently, the European Commission has claimed that the end-of-life recycling input rate is as low as 0.3\% (EU 2017).

It is reported that $\mathrm{Nb}$ can be substituted by other materials, as summarized in Table 4 . In any case, a loss of performance or higher cost accompany the substitutes (Papp 2017). It should also be noted that the possible substitutes themselves (e.g. W) are critical or mine production is much lower than for $\mathrm{Nb}$ (e.g. Ta). Therefore, it is essential to reintroduce $\mathrm{Nb}$ into the product cycle. Demand for new ore could be reduced through improved scrap management. 
TABLE 2: Possible substitutes for Co (Shedd 2017a).

\begin{tabular}{l|l} 
Application & Possible substitutes \\
\hline Magnets & Barium or strontium ferrites, neodymium-iron-boron, nickel-iron alloys \\
\hdashline Paints & Cerium, iron, lead, manganese, vanadium \\
\hdashline For curing unsaturated polyester resins & Cobalt-iron-copper or iron-copper in diamond tools; copper-iron-manganese \\
\hdashline $\begin{array}{l}\text { Cutting and wear-resistant materials } \\
\text { Lithium-ion batteries; }\end{array}$ & Iron, iron-cobalt-nickel, nickel, cermets, ceramics \\
\hline Jet engines & Nickel-based alloys, ceramics \\
\hline Petroleum catalysts & Nickel \\
\hline
\end{tabular}

TABLE 3: World Mine Production and estimated reserves of Nb (Papp 2017).

\begin{tabular}{|c|c|c|c|c|}
\hline & \multicolumn{2}{|c|}{ Mine production 2016} & \multicolumn{2}{|c|}{ Estimated reserves } \\
\hline & [t] & Share & {$[1000 \mathrm{t}]$} & Share \\
\hline Brazil & 58,000 & $90 \%$ & 4,100 & $95 \%$ \\
\hline Canada & 5,750 & $9 \%$ & 200 & $5 \%$ \\
\hline Other countries & 570 & $1 \%$ & n.a. & n.a. \\
\hline World total (rounded) & 64,300 & & 4,300 & \\
\hline
\end{tabular}

TABLE 4: Possible substitutes for Nb (Papp 2017).

\begin{tabular}{|c|c|}
\hline Application & Possible substitutes \\
\hline $\begin{array}{l}\text { Alloying elements in high-strength } \\
\text { low-alloy steels }\end{array}$ & Molybdenum and vanadium \\
\hline $\begin{array}{l}\text { Alloying elements in stainless - } \\
\text { and high-strength steels }\end{array}$ & Tantalum and titanium \\
\hline High-temperature applications & $\begin{array}{l}\text { Ceramics, molybdenum, tantalum, } \\
\text { and tungsten }\end{array}$ \\
\hline
\end{tabular}

$\mathrm{Nb}$-containing steel grades should not be mixed with other steel grades, but rather should be remelted for similar alloys.

\subsection{Tungsten}

Tungsten $(\mathrm{W})$ has the highest melting point of the pure metals and is irreplaceable in special industrial applications (BGS 2011). The name tungsten is derived from the Swedish words tung (heavy) and sten (stone) and goes back to Frederik Cronstedt, who described a high-density mineral in 1757 (ITIA 2011). Juan José de D'Elhuyar is considered to be the discoverer of tungsten. In 1783, he reduced tungsten oxide with charcoal (ITIA 2011).

Cemented carbides, also known as hardmetals, are the main use of tungsten and cover $56 \%$ of the market, followed by steel/alloys (20\%), mill products (17\%) and others (7\%) (Somerley 2011). Other applications include catalysts, pigments, lubricants, electronics and electrical applications, solar power, medical and dental applications (Christian et al. 2011). Special attention is paid to $W$ applications in materials under extreme conditions (Schubert et al. 2008).

As Table 5 shows, China is of paramount importance for tungsten production. In 2016, the country accounted for $82 \%$ of mine production. Vietnam, the second largest producer, is lagging behind and has a share of $7 \%$. No data are available for the USA, but it has been reported that a new tungsten mine was opened in northwest Utah in 2016 (Shedd 2017b). In 2016, however, 76\% of the tungsten imported into Europe came from Russia (EC 2014a).

According to Shedd (2011), the recycling rate for tung- sten in the USA was $46 \%$ in 2000 . A recent study (Zeiler et al 2018) shows that on a global scale the end-of-life recycling rate of tungsten (i.e. ratio of old scrap fed back) is $30 \%$ by 2016 and the recycling input rate (i.e. ratio of new and old scrap fed back) is $35 \%$.

Possibilities for W-containing waste materials are described by Testa et al. (2014) and Shishkin et al. (2010), for example. Potential substitutes for $\mathrm{W}$ are summarized in Table 6. In some applications, however, substitution would lead to higher costs or loss of product performance (Shedd $2017 b$ ). Although depleted uranium or lead are not classified critical, their use is extremely problematic due to its toxicity. It should also be noted that tungsten carbide has unique properties which cannot be met by the suggested substitutes. For instance, Mohs harness of WC is 9.5, while MoC lags far behind (5.5). It must be concluded that tungsten is indispensable for certain applications at the moment.

\subsection{Yttrium}

Yttrium $(\mathrm{Y})$ is a transition metal but is also considered to be a rare earth element (REE) along with scandium and the lanthanoids (Connelly et al. 2005). $Y$ is mainly consumed in the form of high-purity oxide compounds for phosphors, in ceramics, electronic devices, lasers, and metallurgical applications (Gambogi 2016).

World production of $Y$ came almost exclusively from China, as Table 7 shows. Minor amounts of mine production are reported for Brazil, India and Malaysia. However, the estimated reserves are quite large (more than 0.5 Million $t$ ) and far exceed mine production, which was estimated at 8,000 to $10,000 \mathrm{t}$ in 2015 (Gambogi 2016). In contrast to mine production, China's dominance of global reserves is less pronounced. As shown in Table 7, only $41 \%$ of reserves are estimated in China followed by the USA, Australia and India. The reserves of $Y$ are linked to those of rare earths (Gambogi 2016).

In many cases, $Y$ is irreplaceable, as substitutes are generally much less effective. Especially in electronics, 
TABLE 5: World Mine Production and estimated reserves of W (Shedd 2017b).

\begin{tabular}{|c|c|c|c|c|}
\hline & \multicolumn{2}{|c|}{ Mine production 2016} & \multicolumn{2}{|c|}{ Estimated reserves } \\
\hline & [t] & Share & {$[1000 t]$} & Share \\
\hline China & 71,000 & $82 \%$ & 1,900 & $61 \%$ \\
\hline Vietnam & 6,000 & $7 \%$ & 95 & $3 \%$ \\
\hline Russia & 2,600 & $3 \%$ & 83 & $3 \%$ \\
\hline Other countries & 1,700 & $2 \%$ & 680 & $22 \%$ \\
\hline Canada & 1,680 * & $2 \% *$ & 290 & $9 \%$ \\
\hline Bolivia & 1,400 & $2 \%$ & n.a. & n.a. \\
\hline Austria & 860 & $1 \%$ & 10 & $0.3 \%$ \\
\hline Spain & 800 & $1 \%$ & 32 & $1 \%$ \\
\hline Rwanda & 770 & $1 \%$ & n.a. & n.a. \\
\hline United Kingdom & 700 & $1 \%$ & 51 & $2 \%$ \\
\hline Portugal & 570 & $1 \%$ & 3 & $0.1 \%$ \\
\hline United States & n.a. & n.a. & n.a. & n.a. \\
\hline World total (rounded) & 86,400 & & 3,100 & \\
\hline
\end{tabular}

* Data for 2015

TABLE 6: Possible substitutes for Co (Shedd 2017b).

\begin{tabular}{|c|c|}
\hline Application & Possible substitutes \\
\hline Cemented tungsten carbides & $\begin{array}{l}\text { Carbides based on molybdenum carbide and titanium carbide, ceramics, ceram- } \\
\text { ic-metallic composites (cermets), tool steel }\end{array}$ \\
\hline Tungsten mill products & Molybdenum \\
\hline Tungsten steels & Molybdenum steels \\
\hline Lighting & Carbon nanotube filaments, induction technology, light-emitting diodes \\
\hline Applications requiring high-density or the ability to shield radiation & Depleted uranium or lead \\
\hline Armor-piercing projectiles & Depleted uranium alloys or hardened steel \\
\hline
\end{tabular}

TABLE 7: World Mine Production and estimated reserves of Y (Cordier 2012).

\begin{tabular}{|c|c|c|c|c|}
\hline & \multicolumn{2}{|c|}{ Mine production 2011} & \multicolumn{2}{|c|}{ Estimated reserves } \\
\hline & {$[t]$} & Share & {$[1000 t]$} & Share \\
\hline China & 8,800 & $99 \%$ & 220 & $41 \%$ \\
\hline India & 55 & $0.6 \%$ & 72 & $13 \%$ \\
\hline Brazil & 15 & $0.2 \%$ & 2.2 & $0.41 \%$ \\
\hline Malaysia & 4 & $0.04 \%$ & 13 & $2.4 \%$ \\
\hline USA & n.a. & n.a. & 120 & $22 \%$ \\
\hline Australia & n.a. & n.a. & 100 & $19 \%$ \\
\hline Sri Lanka & n.a. & n.a. & 0.24 & $0.04 \%$ \\
\hline Other countries & n.a. & n.a. & 17 & $3 \%$ \\
\hline World total (rounded) & 8,900 & & 540 & \\
\hline
\end{tabular}

lasers, and phosphors, Y cannot be replaced by other elements. Yttrium oxide could be substituted by $\mathrm{CaO}$ or $\mathrm{MgO}$ as stabilizer in zirconia ceramics, but a lower toughness has to be accepted (Gambogi 2016).

Yttrium can be extracted from secondary resources preferably by hydrometallurgical processes, as they are also used for primary ores (Innocenzi 2014). Currently, no large scale $Y$ recycling facility is documented (UNEP 2011), but progress is being made, including investigations into the recovery of $Y$ from flat panel displays, spent optical glass and ceramic dusts.

\subsection{Rare Earth Elements}

The rare earth elements (REE) comprise the group of 14 lanthanides, of which promethium exhibits the lowest natural abundance. In addition to the 14 lanthanides, scandium and yttrium also belong to the REE group (Connelly et al. 2005), since these elements have chemical and physical similarities with the lanthanides.

REE are considered to be of critical importance in sus- 
tainable applications. REE and their compounds also find a multitude of applications in various branches of industry. Their demand is due to their use in various high-technology applications, for example, phosphors for fluorescent lamps, high strength permanent magnets, metallurgy, and applications in a number of green energy technologies. The main applications of REE are catalysts, metallurgy, magnets, electronics and in optical, medical, and nuclear technologies (Long et al. 2010).

China plays a dominate role in the production of REE. As shown in Table 8, China accounted $80 \%$ of mine production in 2016 , followed by Australia with an $11 \%$ share. Other producers are of inferior importance. Global mine production in 2016 was around 132,000 t.

REE are relatively abundant in the earth's crust, and there are significant deposits outside China. Even if China hold $80 \%$ of mine production, only $37 \%$ of the estimated reserves are in China. Relevant deposits are located in Brazil, Thailand, Russia and India. As summarized in Table 8 , minor REE deposits are estimated in several other countries.

Despite their highly fragmented applications, viable recycling technologies are already available today. In reality, however, less than $1 \%$ of REE are currently returned to the production cycle. (UNEP 2011, Tunsu et al. 2015). It is estimated that improvements in recycling can be achieved, particularly in the area of magnets, fluorescent lamps, batteries and catalysts (Jowitt 2018).

\section{CONCLUSIONS}

The present paper elucidates the availability, critical nature, and analysis of production value chains and downstream processes of for selected critical elements: cobalt, niobium, tungsten, yttrium, and the rare earth elements. The European share of reserves and mine production of these crucial elements is very low or even zero. Mine production is often concentrated in a single or very few countries. For Yttrium, 99\% of mine production is in China. As the selected elements are crucial for the European industry, actions to reduce the dependency are strongly encouraged. On the one hand, the COST Action CA15102 evaluates the possibilities of replacing these critical materials with common materials without significant loss of performance. On the other hand, the demand for critical materials can be reduced by substituting new ores by secondary raw materials. It is evident that recycling needs to be significantly increased, as current recycling rates fall to zero (e.g. for Co).

\section{AKNOWLEDGEMENTS}

This publication is based upon work from COST Action CA15102 supported by COST (European Cooperation in Science and Technology): "Solutions for Critical Raw Materials Under Extreme Conditions (CRM-EXTREME)", Working Group WG 4 - Value chain impact, www.crm-extreme.eu. Furthermore, the authors would like to acknowledge networking support from COST CA15102.

\section{REFERENCES}

Bauccio M. (1993). ASM Metals Reference Book 3rd Revised edition, pp 120-122.

BGS (2011). Tungsten Minerals Profile, British Geological Survey, available at: http://www.bgs.ac.uk/downloads/start.cfm?id=1981 (accessed 28 June 2017).

Birat J.-P, Sibley S.F. (2011). Appendix C. Review of Ferrous Metal Recycling Statistics, in: Recycling Rates of Metals - A Status Report, A Report of the Working Group on the Global Metal Flows to the International Resource Panel. Graedel T.E., Allwood J., Birat J.-P., Reck B.K., Sibley S.F., Sonnemann G., Buchert M., Hagelüken C.

CDI (2006). Cobalt facts - Properties, Cobalt Development Institute. available at: http://www.thecdi.com/cdi/images/documents/ facts/COBALT_FACTS-Properties_and_Main_Uses.pdf (accessed 28 June 2017).

TABLE 8: World Mine Production and estimated reserves of REE (Gambogi 2017).

\begin{tabular}{|c|c|c|c|c|}
\hline & \multicolumn{2}{|c|}{ Mine production 2016} & \multicolumn{2}{|c|}{ Estimated reserves } \\
\hline & {$[t]$} & Share & {$[1000 t]$} & Share \\
\hline China & 105,000 & $80 \%$ & 44,000 & $37 \%$ \\
\hline Australia & 14,000 & $11 \%$ & 3,400 & $3 \%$ \\
\hline United States & $5,900 *$ & $4 \%$ & 1,400 & $1 \%$ \\
\hline Russia & 3,000 & $2 \%$ & 18,000 & $15 \%$ \\
\hline India & 1,700 & $1 \%$ & 6,900 & $6 \%$ \\
\hline Brazil & 1,100 & $1 \%$ & 22,000 & $18 \%$ \\
\hline Thailand & 800 & $1 \%$ & 22,000 & $18 \%$ \\
\hline Malaysia & 300 & $0.2 \%$ & 30 & $0.03 \%$ \\
\hline Vietnam & 300 & $0.2 \%$ & n.a. & n.a. \\
\hline South Africa & n.a. & n.a. & 860 & $1 \%$ \\
\hline Canada & n.a. & n.a. & 830 & $1 \%$ \\
\hline Greenland & n.a. & n.a. & 1,500 & $1 \%$ \\
\hline Malawi & n.a. & n.a. & 136 & $0.1 \%$ \\
\hline World total (rounded) & 132,000 & & 120,000 & \\
\hline
\end{tabular}

* Data for 2015 
Chen L., Tang X, Zhang Y., Li L., Zeng Z., Zhang Y. (2011), Process for the recovery of cobalt oxalate from spent lithium-ion batteries, Hydrometallurgy 108, 80-86.

Cheang, C.Y., Mohamed, N., (2016). Removal of cobalt from ammonium chloride solutions using a batch cell through an electrogenerative process. Sep. Purif. Technol. 162, 154-161. doi:10.1016/j. seppur.2016.02.023.

Christian J., Singh Gaur R.P., Wolfe T., Trasorras J. R. L. (2011). Tungsten Chemicals and their Applications, International Tungsten Industry Association, available at: http://www.itia.info/assets/ files/newsletters/Newsletter_2011_06.pdf (accessed 27 June 2017).

Connelly N.G., Damhus T., Hartshorn R.M., Hutton A.T. (2005). Nomenclature of Inorganic Chemistry, International Union of Pure and Applied Chemistry.

Cordier D.J. (2012). Yttrium, Mineral Commodity Summaries 2016, .S Geological Survey, U.S. Department of the Interior, available at: https://minerals.usgs.gov/minerals/pubs/mcs/2012/mcs2012. pdf (accessed 28 June 2017).

EC (2014a). European Commission, Report on Critical Raw Materials For The EU, Report of the Ad hoc Working Group on defining critical raw materials, May 2014, available at: http://ec.europa.eu/ DocsRoom/documents/10010/attachments/1/translations/en/ renditions/pdf (accessed 17 June 2017).

EC (2014b). European Commission, Communication From The Commission To The European Parliament, The Council, The European Economic And Social Committee And The Committee Of The Regions, On the review of the list of critical raw materials for the $\mathrm{EU}$ and the implementation of the Raw Materials Initiative, May 2014, available at: http://eur-lex.europa.eu/legal-content/EN/TXT/ PDF/?uri=CELEX:52014DC0297\&from=EN (accessed 3 July 2017).

EC (2016). Material Information System (MIS) - Cobalt, European Commission, Material Information System (MIS), available at: https:// setis.ec.europa.eu/mis/material/cobalt (accessed 22 June 2017).

EC (2017) Communication from the Commission to the European Parliament, the Council, the European Economic and Social Committee and the Committee of the Regions on the 2017 List of Critical Raw Materials for the EU COM(2017) 490 final (https://ec.europa. eu/transparency/regdoc/rep/1/2017/EN/COM-2017-490-F1-ENMAIN-PART-1.PDF) (Accessed: 2 July 2018).

DIN (2014). Nichtrostende Stähle - Teil 1: Verzeichnis der nichtrostenden Stähle. DIN EN 10088-1:2014-12, German Institute for Standardisation

Donaldson, J. D., Beyersmann, D. (2005). Cobalt and Cobalt Compounds. Ullmann's Encyclopedia of Industrial Chemistry.

Gambogi J. (2016). Yttrium, Mineral Commodity Summaries 2016, .S. Geological Survey, U.S. Department of the Interior, available at: https://minerals.usgs.gov/minerals/pubs/mcs/2016/mcs2016. pdf (accessed 28 June 2017).

Gambogi J. (2017). Rare Earth, U.S. Geological Survey, U.S. Department of the Interior, available at: https://minerals.usgs.gov/minerals/pubs/commodity/rare_earths/mcs-2017-raree.pdf (accessed 28 June 2017)

Hatchett C. (1802). An Analysis of a Mineral Substance from North America, Containing a Metal Hitherto Unknown. Philosophical Transactions of the Royal Society of London vol. 92, 49-66.

Innocenzi V.,De Michelis I., Kopacek B., Vegliò F. (2014), Yttrium recovery from primary and secondary sources: A review of main hydrometallurgical processes, Waste Manage. 34(7), 1237-1250.

ITIA (2011a). History of Tungsten, International Tungsten Industry Association, available at: http://www.itia.info/history.htm (accessed 27 June 2017).

Jian G., Guo J., Wang X., Sun C., Zhou Z., Yu L., Kong F., Qiu J. (2012) Study on separation of cobalt and lithium salts from waste mobilephone batteries, Proc. Environ. Sci. 16, 495-499.
Jowitt S.M., Werner T.T., Weng Z, Mudd G.M. (2018), Recycling of the rare earth elements, Current Opinion in Green and Sustainable Chemistry 13, 1-7.

Long K.R., Gosen B.S.V., Foley, N.K. Cordier D. (2010). The Principal Rare Earth Elements Deposits of the United States. In: U.S.G. Survey (Ed.).

Minerals UK (2009). Cobalt Minerals Profile, British Geological Survey, available at: https://www.bgs.ac.uk/downloads/start.cfm?id=1400 (accessed 21 June 2017).

Nayak P.K., Yang L., Brehm W., Adelhelm P. (2017). From Lithium-Ion to Sodium-Ion Batteries: Advantages, Challenges, and Surprises. Angewandte Chemie 57(1), 102-120.

Pagnanelli F., Moscardini E., Altimari P., Abo Atia T., Toro L. (2016) Cobalt products from real waste fractions of end of life lithium ion batteries, Waste Manage. 51, 214-21.

Papp J.F. (2017). NIOBIUM (COLUMBIUM), U.S. Geological Survey, U.S. Department of the Interior, available at: https://minerals.usgs. gov/minerals/pubs/commodity/niobium/mcs-2017-niobi.pdf (accessed 25 April 2017)

Schubert W.D., Lassner E., Danninger H. (2008). Tungsten in Steel, International Tungsten Industry Association Newsletter, 2-11.

Shedd, K.B. (2004). Cobalt Recycling in the United States in 1998, U.S. GEOLOGICAL SURVEY CIRCULAR 1196-M, M1-M16.

Shedd K.B. (2011). Tungsten recycling in the United States in 2000 , chap. R of Sibley, S.F., Flow studies for recycling metal commodities in the United States: U.S. Geological Survey Circular 1196-R, p. R1-R19, available at https://pubs.usgs.gov/circ/circ1196-R. (accessed 27 June 2017).

Shedd, K.B. (2017a). Cobalt, U.S. Geological Survey, U.S. Department of the Interior, available at: https://minerals.usgs.gov/minerals/ pubs/commodity/cobalt/mcs-2017-cobal.pdf (accessed 21 June 2017)

Shedd, K.B. (2017b). Tungsten, U.S. Geological Survey, U.S. Department of the Interior, available at: https://minerals.usgs.gov/minerals/pubs/commodity/tungsten/mcs-2017-tungs.pdf (accessed 27 June 2017)

Schulz, K., Papp, J., Niobium and Tantalum-Indispensable Twins, U.S. Geological Survey Fact Sheet 2014-3054, June 2014, available at: https://pubs.usgs.gov/fs/2014/3054/pdf/fs2014-3054.pdf (accessed 17 June 2017).

Shishkin A., Mironov V.,Goljandin D., Lapkovsky V. (2010), Mechanical disintegration of Al-W-B waste material, in Proceedings of the World Powder Metallurgy Congress and Exhibition, World PM 2010, vol. 3.

Somerley (2011). Market report on tungsten, fluorspar, bismuth and copper, Somerley Limited.

Testa F., Coetsier C., Carretier E., Ennahali M., Laborie B., Moulin P. (2014). Recycling a slurry for reuse in chemical mechanical planarization of tungsten wafer: Effect of chemical adjustments and comparison between static and dynamic experiments, Microelectron. Eng. 113, 114-122.

TIC (2016). T.I.C. Statistics Overview. Tantalum-Niobium International Study Center, Bulletin No 164, 20.

Tunsu C., Petranikova M., Gergorić M., Ekberg C., Retegan T. (2015). Reclaiming rare earth elements from end-of-life products: A review of the perspectives for urban mining using hydrometallurgical unit operations, Hydrometallurgy 156, 239-258.

UNEP (2011). Recycling Rates of Metals - A Status Report, A Report of the Working Group on the Global Metal Flows to the Interna-tional Resource Panel. Graedel T.E., Allwood J., Birat J.-P., Reck B.K., Sibley S.F., Sonnemann G., Buchert M., Hagelüken C.

Zeiler B., Schubert W.D., Bartl A. (2018) Recycling of Tungsten - Current share, economic limitations and future potential, ITIA Tungsten Newsletter, May 2018, 1-18. 